\title{
Sodium citrate inhibits the proliferation of human gastric adenocarcinoma epithelia cells
}

\author{
YUAN XIA ${ }^{1,2}$, XULONG ZHANG $^{3}$, AGULA BO $^{2}$, JUAN SUN $^{2}$ and MINHUI LI ${ }^{4}$ \\ ${ }^{1}$ Department of Biochemistry and Molecular Biology, College of Life Sciences, Inner Mongolia University, \\ Inner Mongolia Autonomous Region 010021; ${ }^{2}$ School of Public Health, Inner Mongolia Medical University, \\ Inner Mongolia Autonomous Region 010110; ${ }^{3}$ Department of Immunology, College of Basic Medicine, \\ Capital Medical University, Beijing 100069; ${ }^{4}$ Department of National Medicine, Inner Mongolia Institute \\ of Chinese Medicine, Hohhot, Inner Mongolia Autonomous Region 010059, P.R. China
}

Received December 6, 2016; Accepted December 14, 2017

DOI: $10.3892 / 01.2018 .8111$

\begin{abstract}
The objective of the present study was to investigate the cytotoxic effects of sodium citrate on human gastric adenocarcinoma epithelia AGS cells. Numerous cytotoxicity-associated sodium citrate-induced effects were assessed, including cell viability and proliferation, cytokine expression and caspase activity. In vitro studies demonstrated that incubation with sodium citrate $(>3.125 \mathrm{mM})$ inhibited AGS cell viability and proliferation in a dose-dependent manner. Incubation with sodium citrate for $24 \mathrm{~h}$ revealed that the levels of interleukin-1 $\beta$ (IL-1 $\beta$ ), IL-8 and tumor necrosis factor increased with an increasing of dose of sodium citrate, whereas the IL-6 levels exhibited only a slight alteration. In addition, increases in caspase- 3 and -9 activities were associated with increased duration of treatment and dosage of sodium citrate. Collectively, the results of the present study demonstrated that treatment with sodium citrate at higher concentrations or for longer durations exerts a cytotoxic effect on AGS cells via the induction of the intrinsic apoptosis pathway and the alteration in the levels of certain cytokines.
\end{abstract}

\section{Introduction}

Sodium citrate is widely used in the fields of medicine $(1,2)$ and food science as an adjuvant or additive (3). Citrate, an important intermediate in the tricarboxylic acid cycle, serves a notable role in cellular metabolism (4). Under normal physiological conditions, ATP production via oxidative phosphorylation in the mitochondria is an efficient and primary

Correspondence to: Dr Minhui Li, Department of National Medicine, Inner Mongolia Institute of Chinese Medicine, 11 JiangKang Street, Hohhot, Inner Mongolia Autonomous Region 010059, P.R. China

E-mail: prof_liminhui@aliyun.com

Key words: sodium citrate, AGS cells, cytotoxic effect, proliferation, pro-inflammatory cytokine metabolic process, which produces far more ATP molecules from a given amount of glucose than does glycolysis (5). By contrast, the majority of cancer cells exhibit a high level of glycolysis for the generation of ATP to meet their energy requirements; the metabolism of cancer cells is often referred to as the 'Warburg effect' $(6,7)$. Cancer cells primarily metabolize glucose via glycolysis, excreting large amounts of macromolecular precursors, including acetyl-CoA, for the production of fatty acids, non-essential amino acids and nucleotides (8). When glycolysis occurs in this manner, cancer cells undergo fermentation even when mitochondrial function is not impaired, in a process known as 'aerobic glycolysis' (9). Thus, any inhibition of glycolysis may restrict oncogenic proliferation or even halt it entirely, leading to cell death. During glycolysis, citrate acts as an inhibitor of phosphofructokinase and may obstruct the production of ATP or macromolecular precursors, causing the typical cytotoxicity in cancer cells, as has been confirmed in malignant pleural mesothelioma cells (10). Cells deficient in ATP frequently undergo apoptosis $(11,12)$; the induction of cell apoptosis via citrate has been demonstrated in unicellular organisms as well as cancer cells $(13,14)$.

Gastric cancer is one of the most common types of cancer in Asia $(15,16)$. Over the last 4 decades its incidence has decreased globally; however, higher rates of mortality have been observed in East Asian countries than in other areas of the world (16). Genetic and environmental factors may serve a role in the etiology of gastric cancer $(17,18)$, and efforts are being made to further understand and treat this disease.

Several micromolecular compounds have been previously investigated for cytotoxic activity in human gastric adenocarcinoma epithelia AGS cells, including sodium acetate (19), sodium nitrite, and magnesium sulfate $(20,21)$. To varying degrees, the aforementioned compounds exhibited cytotoxic activity, either by altering the expression levels of pro-inflammatory cytokines in AGS cells or by reducing cell viability. In the present study, a range of tests were conducted to understand the anticancer activity exerted by sodium citrate on AGS cells. The antitumor effect of citrate, an anti-glycolytic agent inhibiting phosphofructokinase, was tested on BGC-823 and SGC7901 cell lines (22). Sodium citrate inhibited the growth and proliferation of MGC- 803 cells by blocking the glycolytic 
pathway and regulating the $\mathrm{Bcl}-2$ family genes to induce mitochondria-regulated apoptosis (23).

\section{Materials and methods}

The AGS cell line (Sumitomo Dainippon Pharma Co., Ltd., Osaka, Japan) was originally cultured from stomach adenocarcinoma cells obtained prior to any anticancer treatment (24). Sodium citrate was purchased from Wako Pure Chemical Industries, Ltd. (Osaka, Japan). Quick Cell Proliferation Assay and Annexin V-Phycoerythrin Apoptosis Detection kits were purchased from Medical and Biological Laboratories Co., Ltd. (Aichi,Japan). The Lactate Dehydrogenase(LDH)-Cytotoxicity Assay kit was purchased from Biovision, Inc., (Milpitas, CA, USA) and the Apo Alert DNA Fragmentation Assay kit was purchased from BD Biosciences (Franklin Lakes, NJ, USA). Caspase 3 Activity Assay kit (cat. no.C1116), Caspase 6 Activity Assay kit (cat. no. C1136), Caspase 8 Activity Assay kit (cat. no. C1152) and Caspase 9 Activity Assay kit (cat. no. C1158) were all purchased from Beyotime Institute of Biotechnology (Haimen, China). Ham's F12 medium, 10\% fetal bovine serum, penicillin, streptomycin, L-glutamine and phosphate buffered saline [PBS, (pH 7.4)] were purchased from Gibco (Thermo Fisher Scientific, Inc., Waltham, MA, USA). The 24-well and 96-well plates were purchased from Corning Inc. (Corning, NY, USA). Optical density was measured at $450 \mathrm{~nm}$ with a microplate reader (Ceres UV 900 HD; Bio-Tek Instruments, Inc., Winooski, VT, USA). Total RNA was extracted with Isogen Isolation Reagent kit from Nippon Gene (Tokyo, Japan). Interleukin (IL)-1 $\beta$ (Human) ELISA kit (cat. no. K4794), IL-6 (Human) ELISA kit (cat. no., K4143), IL-8 (Human) ELISA kit (cat. no. K4169) and TNF- $\alpha$ (Human) ELISA kit (cat. no. K4779) were purchased from BioVison, Inc. (Milpitas, CA, USA). Moloney murine leukemia virus reverse transcriptase was purchased from Invitrogen (M-MLV RT; Thermo Fisher Scientific, Inc.). The 5X First-Strand Buffer, DTT, dNTPs and random primers (6-mer) pd (N) 6 was purchased from Takara Bio, Inc. (Otsu, Japan). All solvents, chemicals, and reagents were analytical grade and were purchased from Sigma-Aldrich; Merck KGaA (Darmstadt, Germany).

Chemical agents and cells. Experiments were performed using the human AGS cell line, cultured in Ham's F12 nutrient mixture with L-glutamine, supplemented with penicillin (100 U/ml), streptomycin $(100 \mu \mathrm{g} / \mathrm{ml})$, and $10 \%$ fetal bovine serum (FBS). The culture plate was incubated at $37^{\circ} \mathrm{C}$ in a humidified atmosphere of $5 \% \mathrm{CO}_{2}$ in ambient air. Sodium citrate was used as a stimulant.

Assessment of AGS cell viability. AGS cells were seeded into each a 24-well plate at a density of $8 \times 10^{3}$ cells/well and incubated for $3 \mathrm{~h}$. The Ham's F12 medium was used to dilute sodium citrate to the desired concentration $(0,6.25,12.5,25,50$ and $100 \mathrm{mM}$ ), and the corresponding sodium citrate-containing medium was added to each well. The cells were then incubated at $37^{\circ} \mathrm{C}$ in a $5 \% \mathrm{CO}_{2}$ incubator for an additional 24,48 and $72 \mathrm{~h}$. Control cells were inoculated without sodium citrate. At the end of each incubation, cell suspensions in PBS were treated with $0.04 \%$ Trypan blue at $37^{\circ} \mathrm{C}$ for $2 \mathrm{~min}$, and the dye was thereafter rinsed off with culture medium. Under a light microscope (STZ10, at magnification, $\mathrm{x} 400$ ) with a CCD camera (DP70) (both from Olympus Corporation, Tokyo, Japan), the numbers of stained (dead cells) and unstained cells (live cells) were counted in 8 randomly chosen microscope fields under a light microscope (magnification, $\mathrm{x} 400$ ) using a hemocytometer to determine cell viability.

Cell proliferation assay. Cells were seeded in 96-well plates at a density of $4 \times 10^{3}$ cells/well and incubated at $37^{\circ} \mathrm{C}$ in a $5 \% \mathrm{CO}_{2}$. Simultaneously, cells were treated in triplicate with sodium citrate, with the final sodium citrate concentrations ranging from 0 to $50 \mathrm{mM}(0,1.58,3.13,6.25,12.5,25$ and $50 \mathrm{mM})$. Unstimulated controls were treated with phosphate buffered saline. Cell proliferation was determined at 24, 48, and $72 \mathrm{~h}$ using the Quick Cell Proliferation Assay kit, according to the manufacturer's instructions.

Lactate dehydrogenase release assay. Cell cytotoxicity was measured based on the release of LDH from cells. Briefly, LDH levels in the supernatant of cells pre-treated with $3.125,6.25$, $12.5,25$, or $50 \mathrm{mM}$ sodium citrate for 1,8 , or $24 \mathrm{~h}$ were quantified using the LDH-cytotoxicity assay kit II (BioVision, Inc.). LDH oxidizes lactate to pyruvate, which forms a red formazan product with iodotetrazolium chloride. Dimethyl sulfoxide was added to dissolve the formazan crystals. The amount of formazan present in the supernatant is directly correlated with the number of lysed cells. The optical density was then measured $492 \mathrm{~nm}$ using a spectrophotometer. Triton X-100 (1\%)-treated cells were used as the positive control. The cytotoxicity induced by each dose of citrate was expressed as a percentage of LDH released by treated cells of that released by cells treated with $1 \%$ Triton X-100.

Caspase activity assay. Caspase-3, -6, -8 and -9 activities were determined using a caspase colorimetric assay. Briefly, following treatment with $0,1.25,2.5,5.0,10.0$ or $20.0 \mathrm{mM}$ sodium citrate for 1,3 or $6 \mathrm{~h}$, AGS cells were lysed in caspase lysis buffer (Beyotime Institute of Biotechnology) for $15 \mathrm{~min}$, followed by centrifugation at $16,000 \mathrm{x}$ g at $4^{\circ} \mathrm{C}$ for $15 \mathrm{~min}$. Then, $50 \mu 1$ extracts were incubated with $10 \mu 12 \mathrm{mM}$ enzyme substrate (Ac-DEVD-pNA for caspase-3-like proteinase, Ac-VEID-pNA for caspase-3-like proteinase, Ac-IETD-pNA for caspase-8-like proteinase, and Ac-LEHD-pNA for caspase-9-like proteinase, Beyotime Institute of Biotechnology) in caspase activity assay buffer (40 $\mu \mathrm{l}$; Beyotime Institute of Biotechnology) in a $100-\mu 1$ reaction mixture in 96 -well plates at $37^{\circ} \mathrm{C}$ for $4 \mathrm{~h}$. The absorbance of the mixture was then measured at a wavelength of $405 \mathrm{~nm}$ using a microplate reader. The same volume lysis buffer replaced with sample extracts was used in the control group, and other components unchanged.

Analysis of cytokine protein levels. The levels of IL-1 $\beta$, IL-6, IL-8 and tumor necrosis factor- $\alpha$ (TNF- $\alpha$ ) present in the supernatants of AGS cells exposed to sodium citrate were detected via sandwich ELISA assay. Supernatants were collected and stored at $-20^{\circ} \mathrm{C}$ until the time of assay, at which point RNA was extracted using TRIzol reagent (Life Technologies; Thermo Fisher Scientific, Inc.) according to the manufacturer's instructions. To the standard wells, sample wells and control wells, standard, sample and standard diluents [( $\mathrm{pH} 7.2), 0.01 \mathrm{~mol} / 1$ 
Table I. Sequences of the 5' and 3' primers of the 4 target genes.

\begin{tabular}{|c|c|c|c|}
\hline mRNA & Direction & Primer sequence & PCR fragment size, bp \\
\hline GAPDH & $\begin{array}{l}\text { Sense } \\
\text { Antisense }\end{array}$ & $\begin{array}{l}\text { 5'-TGAAGGTCGGAGTCAACGGATTTGGT-3' } \\
\text { 5'-CATGTGGGCCATGAGGTCCACCAC-3' }\end{array}$ & 985 \\
\hline IL-1 $\beta$ & $\begin{array}{l}\text { Sense } \\
\text { Antisense }\end{array}$ & $\begin{array}{l}\text { 5'-ATAAGCCCACTCTACAGCT-3' } \\
\text { 5'-ATTGGCCCTGAAAGGAGAGA-3' }\end{array}$ & 443 \\
\hline IL-6 & $\begin{array}{l}\text { Sense } \\
\text { Antisense }\end{array}$ & $\begin{array}{l}\text { 5'-GTACCCCCAGGAGAAGATTC-3' } \\
\text { 5'-CAAACTGCATAGCCACTTTC-3' }\end{array}$ & 819 \\
\hline IL-8 & $\begin{array}{l}\text { Sense } \\
\text { Antisense }\end{array}$ & $\begin{array}{l}\text { 5'-GGCACAGTGGAACAAGGACT-3' } \\
\text { 5'-GGCACAGTGGAACAAGGACT-3' }\end{array}$ & 585 \\
\hline TNF- $\alpha$ & $\begin{array}{l}\text { Sense } \\
\text { Antisense }\end{array}$ & $\begin{array}{l}\text { 5'-TCGGGCCAATGCCCTCCTGGCCAA-3' } \\
\text { 5'-GTAGACCTGCCCAGACTCGGCAAA-3' }\end{array}$ & 468 \\
\hline
\end{tabular}

IL-1 $\beta$, Interleukin 1 $\beta$; IL-6, interleukin-6; IL-8, interleukin-8; TNF- $\alpha$, tumor necrosis factor- $\alpha$.

PBS], respectively, was added (50 $\mu 1$ in each well). A total of $100 \mu \mathrm{l}$ of biotin-conjugated anti-Human antibody work solution (IL-1 $\beta$, IL-6, IL-8, TNF- $\alpha$ ) was added into the above wells (standard, sample and control wells). The plates were sealed with an adhesive strip and incubated for $60 \mathrm{~min}$ at $37^{\circ} \mathrm{C}$, then washed 5 times with washing buffer [(pH 7.2)0.01 mol/1 PBS and $0.05 \%$ Tween-20; Beyotime Institute of Biotechnology; code no. PI305-7]. After the final wash, inverted plate, and clapped the plate on absorbent filter papers. $100 \mu \mathrm{l}$ HRP-conjugated secondary antibodies (cat. no. PI305-6; Beyotime Institute of Biotechnology) was added to each well, covered with an adhesive strip and incubated in dark for $60 \mathrm{~min}$ at $37^{\circ} \mathrm{C}$, then washed 4 times with washing buffer as used above. After the final wash, the plate was inverted and clapped on absorbent filter papers. TMB substrate (100 $\mu$ l) (cat. no. PI305-8; Beyotime Institute of Biotechnology) was added into each well, the plate was covered and incubated at $37^{\circ} \mathrm{C}$ in the dark for $20 \mathrm{~min}$. Then, $50 \mu \mathrm{l}$ Stop solution ( $2 \mathrm{~mol} / 1$ sulfuric acid) was added to each well. Then, gentle mixing was performed followed by incubated in the dark for $15 \mathrm{~min}$ at $37^{\circ} \mathrm{C}$. The optical density was read at $450 \mathrm{~nm}$ using a microplate reader within $15 \mathrm{~min}$. Origin 9.0 Software (Microcal Software Inc., Northampton, MA, USA) was used to make a standard curve (linear regression) and calculate the concentration of cytokine in the samples. The intensity of the color change in the ELISA was measured at $450 \mathrm{~nm}$. Results from all experiments were included in the analysis. The minimum detectable dose for these assays were $0.3 \mathrm{pg} / \mathrm{ml}$ for IL- $1 \beta, 5 \mathrm{pg} / \mathrm{ml}$ for IL-6, $8 \mathrm{pg} / \mathrm{ml}$ for IL-8 and $30 \mathrm{pg} / \mathrm{ml}$ for TNF- $\alpha$.

Analysis of cytokine mRNA levels via reverse transcription-polymerase chain reaction (RT-PCR). AGS cells in culture medium were incubated for $24 \mathrm{~h}$ at $37^{\circ} \mathrm{C}$ in the presence of sodium citrate $(6.25,12.5$ and $25 \mathrm{mM})$. Total RNA was then extracted with Isogen. Aliquots $(2.5 \mu \mathrm{g})$ of total RNA were incubated at $70^{\circ} \mathrm{C}$ for $5 \mathrm{~min}$, chilled on ice, and reverse-transcribed in a final volume of $10 \mu \mathrm{l}$ composed of the following components: Moloney murine leukemia virus reverse transcriptase (cat. no. 2640A; Takara Bio, Inc.); 5X First-Strand Buffer; $0.1 \mathrm{mM}$ DTT; $2.5 \mathrm{mmol} \mathrm{dNTPs}$; and random primers (6-mer) pd (N)6. Reactions were performed under the following conditions: $22^{\circ} \mathrm{C}$ for $10 \mathrm{~min} ; 37^{\circ} \mathrm{C}$ for $60 \mathrm{~min}$; and $80^{\circ} \mathrm{C}$ for $5 \mathrm{~min}$. The resulting cDNAs were stored at $-20^{\circ} \mathrm{C}$ until use. Each cDNA $(1 \mu \mathrm{l})$ was added to $29 \mu \mathrm{l}$ reactions containing $3 \mu \mathrm{l} 10 \mathrm{X}$ PCR reaction buffers (Takara Bio, Inc.), $1 \mu 1,4 \mathrm{nmol}$ of each primer, $0.1 \mu 15 \mathrm{U} / \mu 1$ Taq DNA polymerase, and $\mathrm{H}_{2} \mathrm{O}$. The oligonucleotide primers (19) are summarized in Table I. PCR was performed with an automatic thermal cycler, Promgram Temp control system PC-701 (Biometra GmbH, Gottingen, Germany).

The amplification cycle consisted of an initial denaturation of the template DNA at $95^{\circ} \mathrm{C}$ for $5 \mathrm{~min}$, and then denaturation at $94^{\circ} \mathrm{C}$ for $1 \mathrm{~min}$, annealing at $60^{\circ} \mathrm{C}$ for $1 \mathrm{~min}$ and an extension step at $72^{\circ} \mathrm{C}$ for $1 \mathrm{~min}$. The final cycle included an extension step for $7 \mathrm{~min}$ at $72^{\circ} \mathrm{C}$ to ensure full extension of the product. Aliquots $(10 \mu \mathrm{l})$ of each PCR product were analyzed by electrophoresis through $1.5 \%$ agarose S (Wako Pure Chemical Industries, Ltd.) gels containing ethidium bromide. The GAPDH gene was used as an internal control for normalization (19). The GAPDH expression was additionally used to establish the degree of expression of each cytokine by dividing the cytokine mRNA expression by the level of the GAPDH mRNA expression, which represented the average expression rate of the cytokines.

Statistical analysis. Statistical analysis was performed using SPSS version 16.0 (SPSS, Inc., Chicago, IL, USA). Data from three parallel experiments are expressed as the means \pm standard deviation (SD). Student's t-test was used to perform comparisons between two groups. Multi-group comparisons of the means were performed by one-way analysis of variance with post hoc Student-Newman-Keuls test. The correlation coefficient (R) was calculated for cytokine levels and LDH release by Spearman's rank correlation test. $\mathrm{P}<0.05$ was considered to indicate a statistically significant difference.

\section{Results}

Inhibitory effects of sodium citrate on cell viability of AGS cells. To evaluate the effect of sodium citrate on cell viability, 


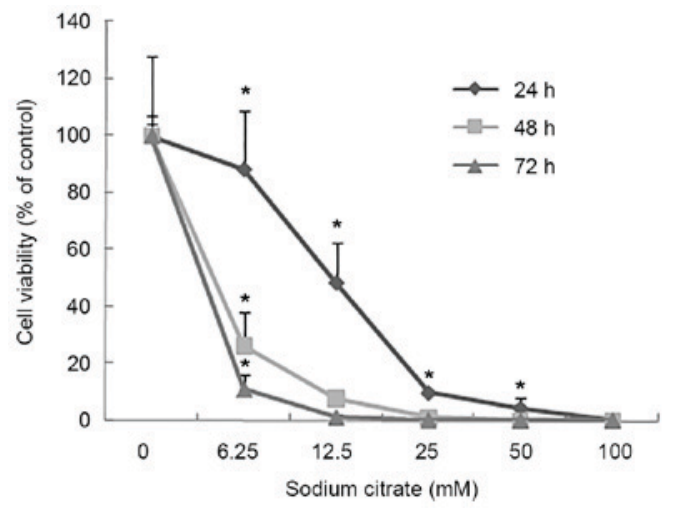

Figure 1. Percentage of viable AGS cells after 24, 48, or 72 h of various concentrations of sodium citrate treatment. AGS cell viability was reduced in a dose-dependent manner. Longer durations of exposure to sodium citrate, with increased dosages, elicited a marked decrease in AGS cell viability. Data are represented as the mean \pm standard deviation. ${ }^{*} \mathrm{P}<0.05$ vs. control Statistical significance indicated by the asterisks.

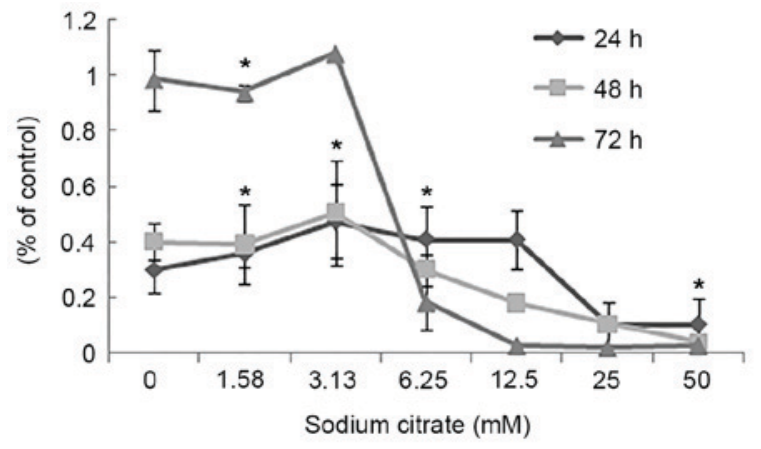

Figure 2. Effects of sodium citrate on AGS cell proliferation. As treatment time increased, the reduction in proliferation was more marked. When the treatment time $>48 \mathrm{~h}$, and the concentrations $>3.125 \mathrm{mM}$, the reduction of proliferation was in an almost dose-dependent manner. Data are represented as the mean \pm standard deviation. ${ }^{*} \mathrm{P}<0.05$ vs. control. Statistical significance indicated by the asterisks.

the viability of AGS cells was observed using a trypan blue exclusion assay following treatment with various concentrations of sodium citrate for 24,48 and $72 \mathrm{~h}$. Cell viability was expressed as a percentage of the control. As presented in Fig. 1, the viability of AGS cells decreased in a dose- and time-dependent manner following treatment with sodium citrate. Compared with the control conditions, high concentrations of sodium citrate, excluding $12.5 \mathrm{mM}$, significantly decreased the viability of AGS cells. In addition, a decrease in cell viability was associated with longer durations of sodium citrate administration. These results were confirmed by the cell proliferation assay, which assessed the effect of various concentrations of sodium citrate on AGS cell proliferation. The rate of AGS cell proliferation increased in a dose-dependent manner at the low concentration (0-3.125 mM); however, the proliferation rate decreased when the concentration exceeded $3.125 \mathrm{mM}$ for each incubation time interval (24, 48 and 72 h; Fig. 2). Cell proliferation was significantly inhibited at the two higher concentrations (25 and $50 \mathrm{mM}$ ). Compared with controls, the proliferation rate decreased $>60 \%$ ( 25 and $50 \mathrm{mM}$ ). In addition, various durations of administration revealed a similar effect to that of variations in dosage; low

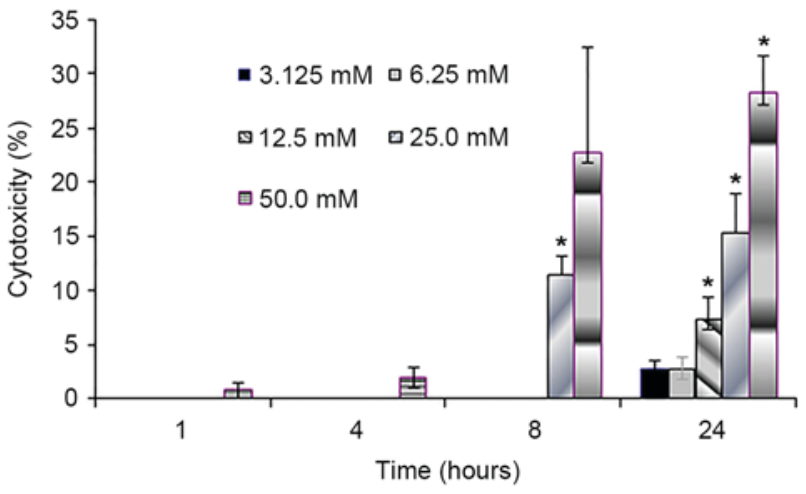

Figure 3. Lactate dehydrogenase release from the AGS cells following pre-treatment with various sodium citrate concentrations for a range of durations. Treatments for 8 and 24 h revealed a positive correlation between the degree of LDH release and concentration of sodium citrate ( $\mathrm{r}=0.9697$ for $8 \mathrm{~h},{ }^{*} \mathrm{P}<0.05 ; \mathrm{r}=0.9906$ for $24 \mathrm{~h}, \mathrm{P}<0.05$ ). Data represent mean values of determinations \pm standard deviation. Statistical significance indicated by the asterisks. ${ }^{*} \mathrm{P}<0.05$ vs. control.

concentrations of sodium citrate $(<3.125 \mathrm{mM})$ promoted AGS cell proliferation; however, concentrations $>3.125 \mathrm{mM}$ inhibited AGS cell proliferation (Fig. 2). These data revealed that the toxicity of sodium citrate for AGS cells was time- and dose-dependent from 3.125 to $50 \mathrm{mM}$ for 24,48 and $72 \mathrm{~h}$. The cytotoxicity of sodium citrate was analyzed with an LDH release assay following the incubation of AGS cells with various concentrations of sodium citrate (Fig. 3). Administration times of 1 or $4 \mathrm{~h}$ had no effect with $3.125-50.0 \mathrm{mM}$ sodium citrate. However, with an administration time of $24 \mathrm{~h}, \mathrm{LDH}$ release increased in association with the increasing concentration of sodium citrate (3.125-50.0 mM; Fig. 3).

AGS cells cultured in the presence of 3.125 and $6.25 \mathrm{mM}$ sodium citrate exhibited $\mathrm{LDH}$ release values of $<3 \%$. Following a $24 \mathrm{~h}$ exposure to $3.125,6.25,12.5,25$ and $50 \mathrm{mM}$ sodium citrate, the values of LDH release were 2.72, 2.83, $7.50,15.40$ and $28.30 \%$, respectively. The results of the present study revealed that 1 and $4 \mathrm{~h}$ exposure to $3.125-50.0 \mathrm{mM}$ sodium citrate had no effect on LDH release within AGS cells; however, longer durations of sodium citrate exposure time were associated with gradual increases in LDH release. Treatments for 8 and $24 \mathrm{~h}$ revealed a positive correlation between the increased degree of LDH release and concentration of sodium citrate (correlation coefficient was 0.9697 for $8 \mathrm{~h}, \mathrm{P}<0.05$; correlation coefficient 0.9906 for $24 \mathrm{~h} ; \mathrm{P}<0.05)$. The result was consistent with the aforementioned cell viability and proliferation experiment.

Effects of sodium citrate on the expression levels of cytokines. To investigate the effect of sodium citrate on the expression of cytokines, supernatants harvested at $24 \mathrm{~h}$ were determined by cytokine-specific ELISA, and the secretion of pro-inflammatory cytokines (TNF- $\alpha$, IL-1 $\beta$, IL-6 and IL-8) from AGS cells stimulated with sodium citrate was analyzed. In the absence of sodium citrate, AGS cells released small amounts of IL-1 $\beta$, IL- 8 and TNF- $\alpha$; however, in the presence of sodium citrate, the levels of IL- $1 \beta$ secretion increased in a dose-dependent manner. The highest levels of IL-1 $\beta$ secretion were 2.3-fold greater compared with that in the control. 
A

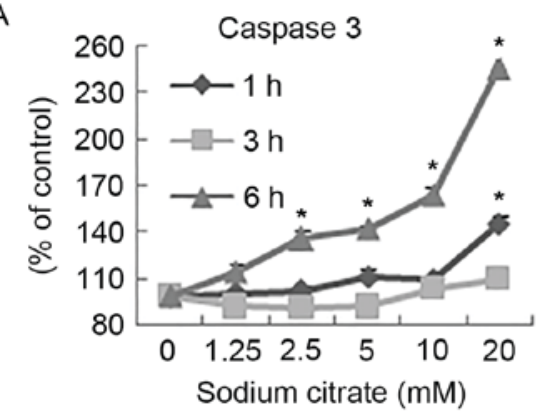

C

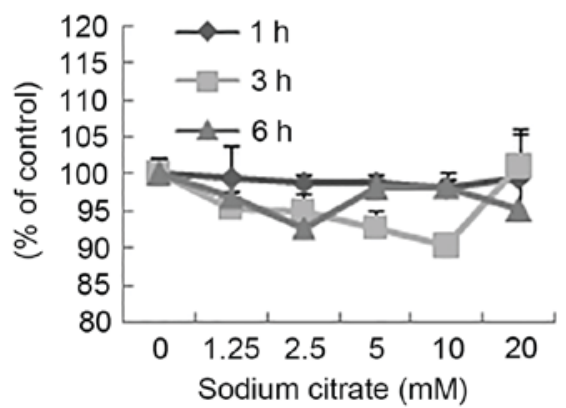

B

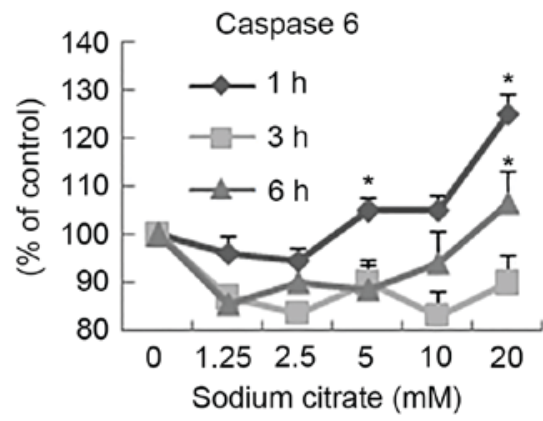

D

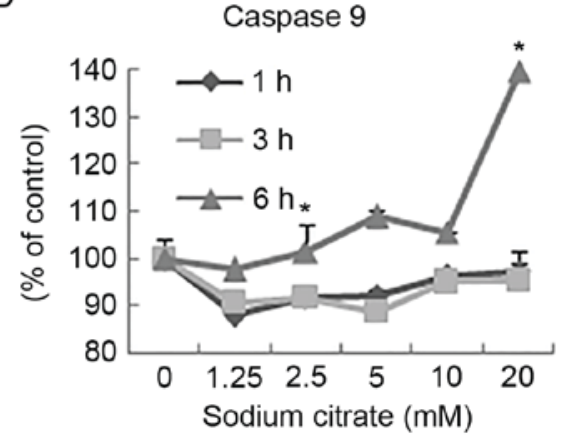

Figure 4. Activities of (A) caspase-3, (B) caspase-6, (C) caspase-8 and (D) caspase-9 within AGS cells treated with the indicated concentrations of sodium citrate for 1,3 or $6 \mathrm{~h}$. Data are represented as the mean \pm standard deviation. ${ }^{*} \mathrm{P}<0.05$ vs. control. Statistical significance indicated by the asterisks.
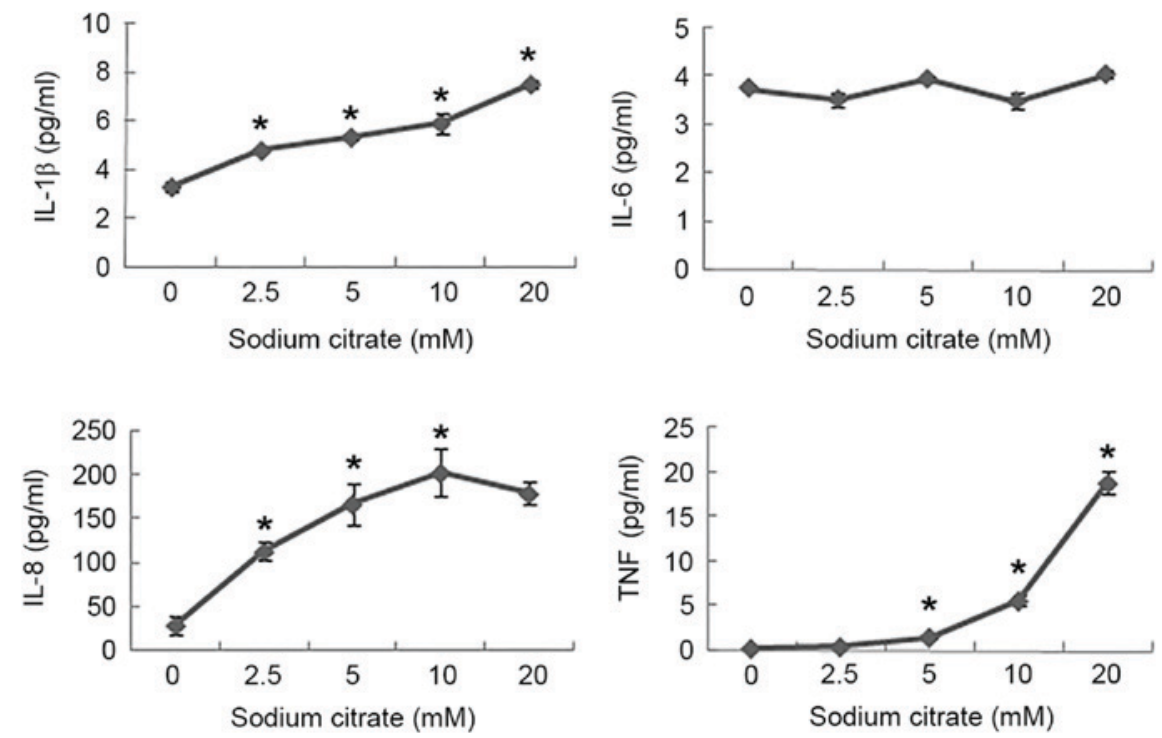

Figure. 5 Cytokines secretion profiles of cultured AGS cells in the presence or absence of sodium citrate. Cytokine protein levels are presented (ng/ml of culture supernatant) in the presence of sodium citrate for $24 \mathrm{~h}(6.25,12.5$ and $25 \mathrm{mM})$. Data are represented as the mean \pm standard deviation. ${ }^{*} \mathrm{P}<0.05 \mathrm{vs}$. control. IL-1 $\beta$, interleukin-1 $\beta$; TNF- $\alpha$, tumor necrosis factor- $\alpha$. Statistical significance indicated by the asterisks.

The levels of IL-8 secretion increased significantly following treatment with $2.5 \mathrm{mM}$ sodium citrate, and increased further with rising concentrations of sodium citrate. The highest level of IL-8 secretion was 7.2-fold greater than the control level in stimulated cells. In addition, the levels of TNF- $\alpha$ increased with $10.0 \mathrm{mM}$ sodium citrate; however, treatment with $20.0 \mathrm{mM}$ sodium citrate further increased the levels of TNF- $\alpha$ to $18.8 \mathrm{pg} / \mathrm{ml}$. Compared with the control, significant alterations in IL-6 levels were not observed (Fig. 4).
To verify the results of the present study, the levels of cytokine mRNAs for IL-1 $\beta$, IL- 6 , IL- 8 and TNF- $\alpha$ were assessed by RT-PCR. The highest levels of IL-1 $\beta$ mRNA was detected with $20 \mathrm{mM}$ sodium citrate treatment. The levels of IL-8 and TNF- $\alpha$ mRNA expression increased with increasing doses of sodium citrate. IL- 6 mRNA expression was not detected at any dose of sodium citrate (Fig. 5). The results of this assay were consistent with those of the previous ELISA assay results. 


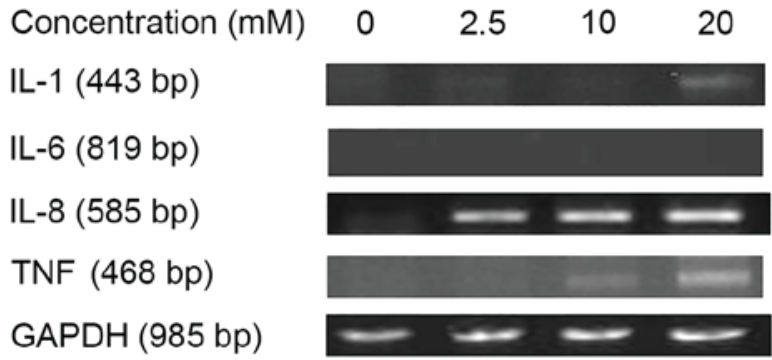

Figure 6. Cytokine mRNA profiles following in vitro treatment of AGS cells with the indicated concentrations of sodium citrate, GAPDH served as the normalization gene. IL-1 $\beta$, interleukin-1 $\beta$; TNF- $\alpha$, tumor necrosis factor- $\alpha$.

Effects of sodium citrate on caspase activity. The activities of caspase- 3 and -9 in AGS cells increased following $6 \mathrm{~h}$ of treatment with different concentrations of sodium citrate compared with the control (Fig. 4A and D). Treatment of cells with $20 \mathrm{mM}$ sodium citrate for $1 \mathrm{~h}$ resulted in a marked increase in the activities of caspase- 3 and -6 compared with cells treated with the control. The highest activities of all caspases were observed in the $20 \mathrm{mM}$ treatment groups, with the exception of caspase-8, which was not altered with varying duration or concentration, compared with the control (Fig. 6).

\section{Discussion}

A potential strategy to inhibit cancer cell growth may involve the targeting of glycolytic inhibitors (25). As high concentrations of citrate may inhibit the glycolytic pathway $(26,27)$, the cytotoxic effects of citrate on AGS cells were investigated in the present study. Low concentrations of citrate $(<3.125 \mathrm{mM})$ promoted AGS cell proliferation; however, higher doses were cytotoxic. This result may be caused by citrate affecting glucose metabolism within cancer cells (27). Furthermore, the cytotoxic effect of citrate within cancer cells has been reported to exert a synergistic effect with certain anticancer drugs (10). Additionally, as defined by the Warburg effect, LDH is an enzyme involved in obtaining energy following aerobic glycolysis in cancer cells. The positive correlation between the increased degree of LDH release and concentration of sodium citrate treatment indicated that the cytotoxic effect of sodium citrate observed in AGS cells increased as the concentration or time of treatment increased.

Caspases are central components of the apoptotic process, which function as initiators or executors in programmed cell death (28). Caspase- 8 and -9 have been reported to act as initiators of apoptosis, and caspase- 3 and -6 as executors (29). In the present study, the activities of caspase- $3,-6,-8$ and -9 were investigated. After $6 \mathrm{~h}$ of treatment with various concentrations of sodium citrate, the activities of caspase- 3 and caspase-9 increased. These results are consistent with those of a previous study (30), which demonstrated the induction of caspase- 3 and -8 cascade activation, resulting in cancer cell apoptosis. The experiment also demonstrated that, when AGS cells were exposed to $20 \mathrm{mM}$ citrate for $1 \mathrm{~h}$, caspase- 6 was likely to be involved in regulating this apoptosis, as its activity level decreased shortly afterwards. However, the activity of caspase- 8 was not affected by any concentration of sodium citrate (31). Therefore, treatment with sodium citrate induced
AGS cell-apoptosis via the intrinsic, and not the extrinsic apoptotic pathway (32).

Cytokines are mediators involved in gastric physiology, as well as pathophysiology, and may serve important roles in the etiology of gastric cancer (33). In addition, numerous caspases serve as critical mediators in the integration of apoptotic and inflammatory pathways (32). However, certain pro-inflammatory cytokines, such as IL-1 $\beta$, may be activated by caspase- 8 ; the results of the present study revealed that IL- $1 \beta$ and IL- 8 levels were increased, although an increase in caspase- 8 activity was not observed within AGS cells. This indicated that the levels of IL- $1 \beta$ and IL- 8 may be regulated by other caspases, such as caspase- 1 or -11 , or by various mechanisms. Although TNF- $\alpha$ was not detected in the ELISA assay, it was detected by RT-PCR. The discrepancy between the ELISA and RT-PCR results may be due to sodium citrate affecting only the expression of TNF- $\alpha$ mRNA. In addition, the levels of IL-6 were possibly too low for detection in the present study.

As observed in the extrinsic apoptosis pathway, moderate levels of IL- 6 and IL- 8 cytokines are detected in Fas-mediated apoptosis (33). Fas receptor stimulation has also been demonstrated to induce phagocyte migration in vivo (33), indicating that it activates the apoptotic and pro-inflammatory pathways, thus facilitating the elimination of dying cells. Therefore, the apoptosis of AGS cells induced by sodium citrate via the intrinsic pathway is likely to occur via the same mechanism. This cytotoxic mechanism probably operates synergistically, inducing apoptosis via the intrinsic pathway and altering the cytokine expression profile.

In the present study, exposing AGS cells to higher concentrations of sodium citrate or longer durations of treatment may elicit a cytocidal effect, which was observed via a reduction in cell viability and proliferation, an increase in LDH release, an induction of the intrinsic pathway of apoptosis and alterations in the expression levels of certain cytokines.

\section{Acknowledgements}

The present study was supported by the National Natural Science Foundation of China (grant nos. 81473017 and 31460249 ).

\section{Competing interests}

The authors declare that they have no competing interests.

\section{References}

1. Leumann E, Hoppe B, Neuhaus T and Blau N: Efficacy of oral citrate administration in primary hyperoxaluria. Nephrol Dial Transpl 10 (Suppl 8): S14-S16, 1995.

2. Phillips R, Hanchanale VS, Myatt A, Somani B, Nabi G and Biyani CS: Citrate salts for preventing and treating calcium containing kidney stones in adults. Cochrane Database Syst Rev: CD010057, 2015.

3. Pastorino J, Hansen CL and McMahon DJ: Effect of sodium citrate on structure-function relationships of Cheddar cheese. J Dairy Sci 86: 3113-3121, 2003.

4. Westergaard N, Waagepetersen HS, Belhage B and Schousboe A: Citrate, a ubiquitous key metabolite with regulatory function in the CNS. Neurochem Res 42: 1583-1588, 2017.

5. Wang JY,Zhu SG and Xu CF (eds): Essential Biochemistry. 1stEdition, Volume 20, Higher Education Press, Beijing, pp340-342, 2010.

6. Warburg $\mathrm{O}$, Wind $\mathrm{F}$ and Negelein E: The metabolism of tumors in the body. J Gen Physiol 8: 519-530, 1927. 
7. Warburg O: On the origin of cancer cells. Science 123: 309-314, 1956.

8. Moreno-Sánchez R, Rodríguez-Enríquez S, Marín-Hernández A and Saavedra E: Energy metabolism in tumor cells. FEBS J 274: 1393-1418, 2007.

9. Vander Heiden MG, Cantley LC and Thompson CB: Understanding the Warburg effect: The metabolic requirements of cell proliferation. Science 324: 1029-1033, 2009.

10. Zhang X, Varin E, Allouche S, Lu Y, Poulain L and Icard P: Effect of citrate on malignant pleural mesothelioma cells: A synergistic effect with cisplatin. Anticancer Res 29: 1249-1254, 2009.

11. Izyumov DS, Avetisyan AV, Pletjushkina OY, Sakharov DV, Wirtz KW, Chernyak BV and Skulachev VP: 'Wages of fear': Transient threefold decrease in intracellular ATP level imposes apoptosis. Biochim Biophys Acta 1658: 141-147, 2004.

12. Vander Heiden MG, Chandel NS, Schumacker PT and Thompson CB: Bcl-xL prevents cell death following growth factor withdrawal by facilitating mitochondrial ATP/ADP exchange. Mol Cell 3: 159-167, 1999.

13. Yousefi S, Owens JW and Cesario TC: Citrate shows specific, dose-dependent lympholytic activity in neoplastic cell lines. Leuk Lymphoma 45: 1657-1665, 2004.

14. Wang YS and Wang ZY: Sodium citrate induces apoptosis in biocontrol yeast Cryptococcus laurentii. J Appl Microbiol 113: 135-142, 2012.

15. Sun J, Misumi A, Shimaoka K, Aoki F and Esaki F: Stomach cancer-related mortality. Eur J Cancer Prev 10: 61-67, 2001.

16. Hamashima C: Current issues and future perspectives of gastric cancer screening. World J Gastroenterol 20: 13767-13774, 2014.

17. Wang XQ, Terry PD and Yan H: Review of salt consumption and stomach cancer risk: Epidemiological and biological evidence. World J Gastroenterol 15: 2204-2213, 2009.

18. Reeves GK, Pirie K, Green J, Bull D and Beral V; Million Women Study Collaborators: Comparison of the effects of genetic and environmental risk factors on in situ and invasive ductal breast cancer. Int J Cancer 131: 930-937, 2012.

19. Sun J, Bi L, Chi Y, Aoki K and Misumi J: Effect of sodium acetate on cell proliferation and induction of proinflammatory cytokines: A preliminary evaluation. Food Chem Toxicol 43: $1773-1780,2005$

20. Sun J, Aoki K, Wang W, Guo A and Misumi J: Sodium nitrite-induced cytotoxicity in cultured human gastric epithelial cells. Toxicol in Vitro 20: 1133-1138, 2006.

21. Zhang X, Bo A, Chi B, Xia Y, Su X and Sun J: Magnesium sulfate induced toxicity in vitro in AGS gastric adenocarcinoma cells and in vivo in mouse gastric mucosa. Asian Pac J Cancer Prev 16: 71-76, 2015.
22. Lu Y, Zhang X, Zhang H, Lan J, Huang G, Varin E, Lincet $H$, Poulain L and Icard P: Citrate induces apoptotic cell death: A promising way to treat gastric carcinoma? Anticancer Res 31: 797-805, 2011

23. Guo X, Zhang X, Wang T, Xian S and Lu Y: 3-Bromopyruvate and sodium citrate induce apoptosis in human gastric cancer cell line MGC-803 by inhibiting glycolysis and promoting mitochondria-regulated apoptosis pathway. Biochem Biophys Res Commun 475: 37-43, 2016.

24. Barranco SC, Townsend CM Jr, Casartelli JC, Macik BG, Burger NL, Boerwinkle WR and Gourley WK: Establishment and characterization of an in vitro model system for human adenocarcinoma of the stomach. Cancer Res 43: 1703-1709, 1983.

25. Xintaropoulou C, Ward C, Wise A, Marston H, Turnbull A and Langdon SP: A comparative analysis of inhibitors of the glycolysis pathway in breast and ovarian cancer cell line models. Oncotarget 6: 25677-25695, 2015.

26. Randle PJ, Denton RM and England PJ: Citrate as a metabolic regulator in muscle and adipose tissue. Biochem Soc Symp 27: 87-103, 1968

27. Icard P, Poulain L and Lincet $\mathrm{H}$ : Understanding the central role of citrate in the metabolism of cancer cells. Biochim Biophys Acta 1825: 111-116, 2012.

28. Elinos-Báez CM, Maldonado V and Meléndezzajgla J: Caspases: Apoptosis inducing molecules. Gac Med Mex 139: 493-499, 2003 (In Spanish)

29. Riedl SJ and Shi Y: Molecular mechanisms of caspase regulation during apoptosis. Nat Rev Mol Cell Biol 5: 897-907, 2004.

30. Kruspig B, Nilchian A, Orrenius S, Zhivotovsky B and Gogvadze V: Citrate kills tumor cells through activation of apical caspases. Cell Mol Life Sci 69: 4229-4237, 2012.

31. Kim GY, Park SY, Jo A, Kim M, Leem SH, Jun WJ, Shim SI, Lee SC and Chung JW: Gecko proteins induce the apoptosis of bladder cancer 5637 cell by inhibiting Akt and activating intrinsic caspase cascade. BMB Rep 48: 531-536, 2015.

32. Creagh EM: Caspase crosstalk: Integration of apoptotic and innate immune signalling pathways. Trends Immunol 35: 631-640, 2014.

33. Persson C, Canedo P, Machado JC, El-Omar EM and Forman D: Polymorphisms in inflammatory response genes and their association with gastric cancer: A HuGE systematic review and meta-analyses. Am J Epidemiol 173: 259-270, 2011. 